Bangladesh J. Plant Taxon. 28(2): 413-428, 2021 (December)

(C) 2021 Bangladesh Association of Plant Taxonomists

\title{
CYANOBACTERIAL DIVERSITY AND PHYSICOCHEMICAL CHARACTERISTICS OF THERMAL SPRINGS IN THE KÜTAHYA PROVINCE OF TURKEY
}

\author{
SEVILAY ÖZTÜRK* \\ Department of Biology, Faculty of Sciences and Letters, \\ Manisa Celal Bayar University, Manisa, Turkey
}

Keywords: Biodiversity; Cyanobacteria; Thermal springs; RDA analyses; Turkey.

\begin{abstract}
Thermal springs are very difficult environments for organisms due to the high temperature, and physicochemical parameters. Cyanobacteria, which are photosynthetic prokaryotes, are best adapted to these environments. Kütahya is an important thermal area in Turkey. The aim of the study was to determine the cyanobacterial flora with a morphologic and ecologic approach in the 11 thermal. The physicochemical properties of the thermal springs in Kütahya province were measured. The thermal springs are alkaline $(\mathrm{pH}>6)$ with an average temperature of $52^{\circ} \mathrm{C}$. As a result, 54 cyanobacteria taxa were identified. Oscillatoriales were the predominant order in terms of taxa diversity (24 taxa) and biomass size. Statistical analyses were conducted to reveal the physicochemical properties of the thermal springs and the distribution of cyanobacteria in detail. According to these analyses, the thermal springs were classified into two main groups with a Piper. As a result of the RDA analysis under CANOCO 5.0, the total variation was 55.45455 , and the first two axes explained a total of $57.43 \%$ of the variance. There was a significant difference $(P<0.001)$ in the comparison of the physicochemical parameters including $\mathrm{pH}, \mathrm{EC}$, TDS, and temperature values of the thermal springs in the Kruskal Wallis tests.
\end{abstract}

\section{Introduction}

Cyanobacteria are ecologically important because of their role in oxygen production and in assimilation of carbon and nitrogen. Although life is difficult in thermal springs, the cyanobacteria are the most adapted organisms for this environment. Cyanobacteria are the most commonly reported microbial groups constituting thermophilic mats and considered the major primary producers in these type of habitats (Castenholz, 1973). Due to their abilities, the determination of diversity of cyanobacteria in thermal springs is gaining importance. Studies of thermal springs allow us to know which cyanobacterial taxa can adapt to the thermal environment. The diversity of cyanobacteria in thermal springs depends on two basic factors: i) the temperature of the thermal spring, ii) the dissolved chemicals in the thermal spring.

There are more than 600 thermal springs in Turkey (Özsahin and Kaymaz, 2013). Despite this, studies of the biology of thermal springs are very limited (Adigüzel et al., 2009; Yedier et al., 2016). Biodiversity studies of thermal algae in Turkey began in Pamukkale with collected algae (Regel and Skuja, 1937) and continued with Güner (1966, 1967, 1970); Aysel et al. (1992); Pentecost et al., (1997); Ünal (1996); Ulcay Öztürk et al., (2006; 2007); Yüksel et al., (2009); Demirel and Sukatar, (2011); Ulcay and Kurt, (2014a,b,c), Altunoz et al., (2016); Öztürk Ulcay and Kurt (2017); Öztürk Ulcay et al., (2017); Kalkan et al., (2020) and Öztürk, (2020).

Corresponding author, E-mail: seviozturk@yahoo.com 
Numerous cyanobacteria taxa have been reported in thermal springs throughout the world. Regarding their morphotypes characteristics, Sompong et al. (2005) identified 19 genera and 36 cyanobacteria taxa from nine thermal springs $\left(30-80^{\circ} \mathrm{C}\right)$ in northern Thailand. Debnath et al. (2009) reported 18 taxa distributed in 12 genera at three geothermal springs in Bakreswar in India. In total, 43 taxa belonging to 20 genera of the planktonic cyanobacteria were identified at four hot springs in Iran by Heidari et al. (2013). Roy et al. (2015) identified 16 taxa spread over 14 genera in the Bakreswar geothermal springs in India. Based on morphology, the distribution of 31 cyanobacteria taxa $\left(30-38.2^{\circ} \mathrm{C}\right)$ from Thermopylae thermal spring in Greece were identified by Kanellopoulos et al. (2016). Singh et al. (2018b) reported 22 taxa under 11 genera based on the morphology at nine thermal springs in the northwestern Himalayas.

The aim of the study was to determine the cyanobacterial flora of thermal springs in the Kütahya province, an important thermal area in Turkey including morphological and ecological aspects. In this context, the results obtained by morphological methods have been studied in an attempt to determine species diversity. Additionally, the thermal springs in Kütahya province measured to determine their physicochemical properties. The piper diagram provided ease in classification and comparison of the thermal springs in Kütahya province where the anion and cation of the water taken from 11 thermal springs was compared. In addition to all this, the relationship between the physicochemical parameters, the sampling sites, and the taxa were explored with the redundancy analysis (RDA) (CANOCO 5.0.). Kruskal-Wallis tests were applied under Statistical Package for the Social Sciences (SPSS) to reveal the statistical significance of differences or similarities of the physicochemical parameters and the taxa numbers of the sampling sites.

\section{Materials and Methods}

Sampling sites

Kütahya is situated on major fault lines in the western Anatolian region of Turkey. In this study, a large number of sampling sites with different physicochemical characteristics were selected from 11 thermal springs (Fig. 1). These sites were scattered over an area of approximately $2500 \mathrm{~km}^{2}$ ranging from an altitude of $588 \mathrm{~m}$ to $1462 \mathrm{~m}$, and most of them had thermal spring facilities like spas or thermal hotels.

\section{Physicochemical characteristics of the thermal springs}

Water samples were collected in sterile glass bottles from the sampling sites while collecting cyanobacteria samples. The temperature $\left(\mathrm{T}^{\circ} \mathrm{C}\right), \mathrm{pH}$, conductivity $(\mathrm{EC}-\mathrm{mS} / \mathrm{cm})$, and total dissolved solids (TDS-mg/l) were measured using a Hanna HI 9812-5 Portable $\mathrm{pH} / \mathrm{EC} / \mathrm{TDS} / \mathrm{Temperature}$ Meter (Europa-Romania) in-situ. The water samples were labelled and transported to the laboratory for chemical analysis. Fluoride $\left(\mathrm{F}^{-}\right)$, chloride $\left(\mathrm{Cl}^{-}\right)$, bromine $\left(\mathrm{Br}^{-}\right)$, nitrite $\left(\mathrm{NO}_{2}{ }^{-}\right)$, nitrate $\left(\mathrm{NO}_{3}^{-}\right)$, phosphate $\left(\mathrm{PO}_{4}^{-3}\right)$, sulphate $\left(\mathrm{SO}_{4}^{-2}\right)$ analyses were performed by DIONEX ICS-5000 Ion Chromatography/ppm. Other chemical analyses were performed by Perkin Elemer Optima $8000 / \mathrm{mg} / \mathrm{L}$ for other chemical factors including calcium $\left(\mathrm{Ca}^{++}\right)$, ferrous $\left(\mathrm{Fe}^{2+}\right)$, potassium $\left(\mathrm{K}^{+}\right)$, magnesium $\left(\mathrm{Mg}^{+}\right)$, sodium $\left(\mathrm{Na}^{+}\right)$, silicon $(\mathrm{Si})$, and manganese $\left(\mathrm{Mn}^{+}\right)$. Ammonium $\left(\mathrm{NH}_{4}{ }^{+}\right)$analyses were performed by Nesslerizasyon/ppm. All chemical analysis were performed at the Manisa Celal Bayar University-Applied Science Research Center (Manisa, Turkey).

A Piper diagram provides convenience in the classification and comparison of natural springs. The similarities and differences of these thermal springs were investigated with the Piper diagram, and the eleven springs were classified according to their chemical composition with the Piper 
diagram using GW Chart Software (USGS) and Microsoft Excel 2016 (Piper, 1944; Winston, 2020).

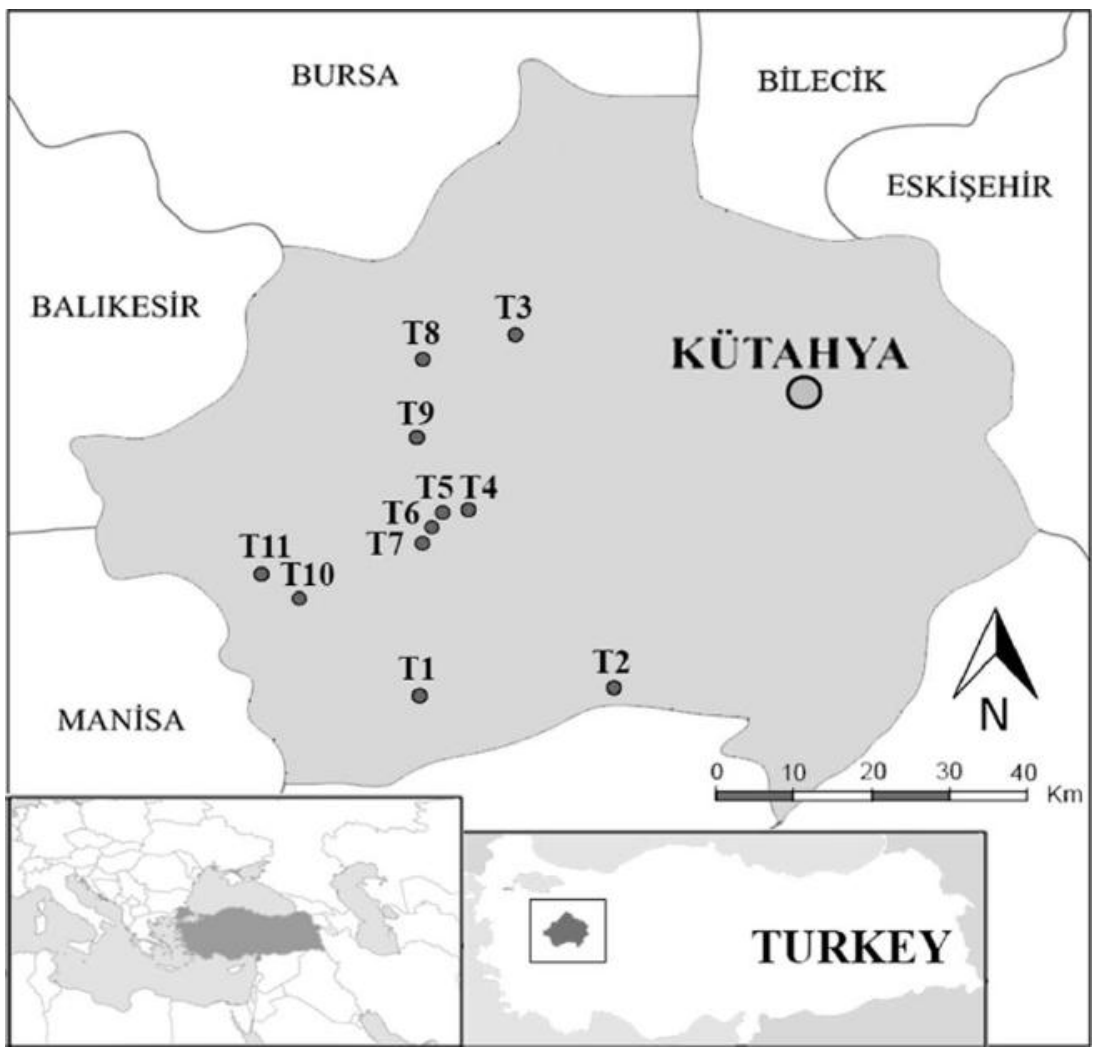

Fig. 1. Thermal Spring Sample Site Names and Locations in Kütahya Province. T1- Gediz-Ilica (38 $\left.56^{\circ} 22^{\prime \prime N} 29^{\circ} 15^{\prime} 31^{\prime \prime E}\right)$,

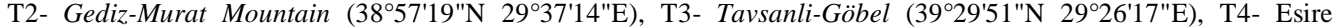

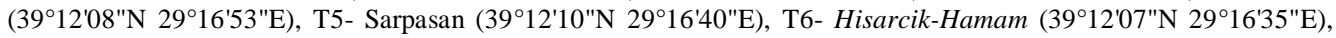
T7- Hisarcik-Sefaköy $\left(39^{\circ} 10^{\prime} 33^{\prime \prime N} 29^{\circ} 15^{\prime} 37^{\prime \prime E}\right)$, T8- Günlüce-Dereli (39²7'46"N 2915'55"E), T9- Emet (39²0'32"N

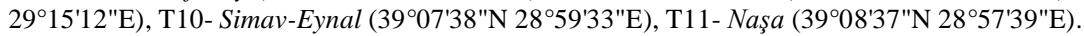

\section{Sampling and identification of cyanobacteria}

Cyanobacteria samples were collected between February 2014 and January 2015. Collected samples were placed in $50 \mathrm{ml}$ falcon tubes for morphological identification. All samples were labeled and transported to the laboratory. Collected samples were divided into two parts in the laboratory, one used in direct observations, and the other part fixed with $4 \%$ formalin solution to prevent degradation of the characteristics of the taxa.

Microscopic studies were conducted in the laboratory using an Olympus BX 50 (phasecontrast) microscope, and taxonomical characteristics were determined and photographed using the Sony DSC-TX7 camera for morphological identification. The identification of the taxa was made according to previous studies including Komárek and Anagnostidis (2000, 2005), John et al., (2002) and Komárek, (2013). The nomenclature was checked on the AlgaeBase database (Guiry and Guiry, 2021). 


\section{Statistical analysis}

The relationship between the physicochemical variables of the thermal springs and the distribution of cyanobacteria taxa was assessed by redundancy analysis (RDA) and detrended correspondence analysis (DCA). The analysis was carried out using CANOCO 5.0 software for Windows (Ter Braak and Smilauer, 2012). Initially, a DCA was performed to determine the gradient length and which model (linear or unimodal) the studied gradient is suitable for. According to the DCA results, it was seen that the available data was suitable for RDA analysis. To obtain gradients not associated with the coverable, a forward selection of the environmental variables was performed. Physicochemical properties were determined through a Monte Carlo test (499 permutations), taking into account all canonical axes.

Kruskal-Wallis tests were performed using SPSS 20.00 software to determine whether the differences (in terms of physicochemical parameters) between the thermal springs were statistically significant. Kruskal-Wallis is a non-parametric test and is used for multiple data comparisons. The Kruskal-Wallis test was used to determine the importance of $\mathrm{pH}, \mathrm{EC}$, TDS, and temperature values of the eleven thermal springs.

\section{Results and Discussion}

Physicochemical characteristics of the thermal springs

Some chemical parameters of the eleven thermal springs in Kütahya as well as the annual average $\mathrm{pH}$, temperature, and EC and TDS measurements are shown in Table 1. The results indicate that the thermal springs were alkaline $(\mathrm{pH}>6)$, the average temperature was $52^{\circ} \mathrm{C}$, and they were transparent. In addition, it was found that nutrient elements were high, and sulphate and ammonia were below the measurable values in the thermal springs. These physicochemical parameters explain the abundance of cyanobacteria diversity in the thermal springs.

In the Piper diagram, which is the most acceptable method in classifying and comparing natural springs and ground waters, anions and cations are shown in two separate triangles while all ions are shown from a quadrilateral, and this diagram makes classification and comparison of waters easier (Piper, 1944). Based on the Piper diagram, the thermal springs of the Kütahya province were classified into two main groups, one (T2, T4, T5, T6, T7, T9) Ca-Mg-SO ${ }_{4}$, the other one (T1, T3, T8, T10, T11) Na-HCO $-\mathrm{SO}_{4}$ (Fig. 2).

\section{Cyanobacteria taxa}

Collected samples were identified based on morphological characteristics. As a result, the 54 cyanobacteria taxa identified were distributed in five orders (Table 2). Among the identified taxa, Oscillatoriales were dominant with 25 taxa. In this study, Pseudanabaena minima had the highest diversity in the thermal springs of Kütahya. Among the sampling sites, Gediz Ilıca (T1) with 10 taxa and Naşa (T11) with one taxon represented the highest and the lowest species diversity, respectively. The most abundant genera was Leptolyngbya, which almost dominated in the nine thermal springs. The most common taxon was Pseudanabaena minima, which was identified from the three thermal springs.

\section{Statistical analysis}

The relationships between the physicochemical parameters, the sampling sites, and the taxa were explored with an RDA using CANOCO 5.0 software for Windows. Firstly, DCA was performed to find a suitable analysis and gradient lengths were assessed (Axis 1: 0.00; Axis 2: 0.00). Among the physicochemical parameters analyzed, five were included in the forward selection (temperature, $\mathrm{pH}$, TDS, $\mathrm{EC}$, and $\mathrm{PO}_{4}$ ). In the RDA, the physicochemical parameters (T, $\mathrm{pH}$, TDS, EC, and $\mathrm{PO}_{4}$ ), the sampling sites, and the taxa were used as explanatory variables. The 


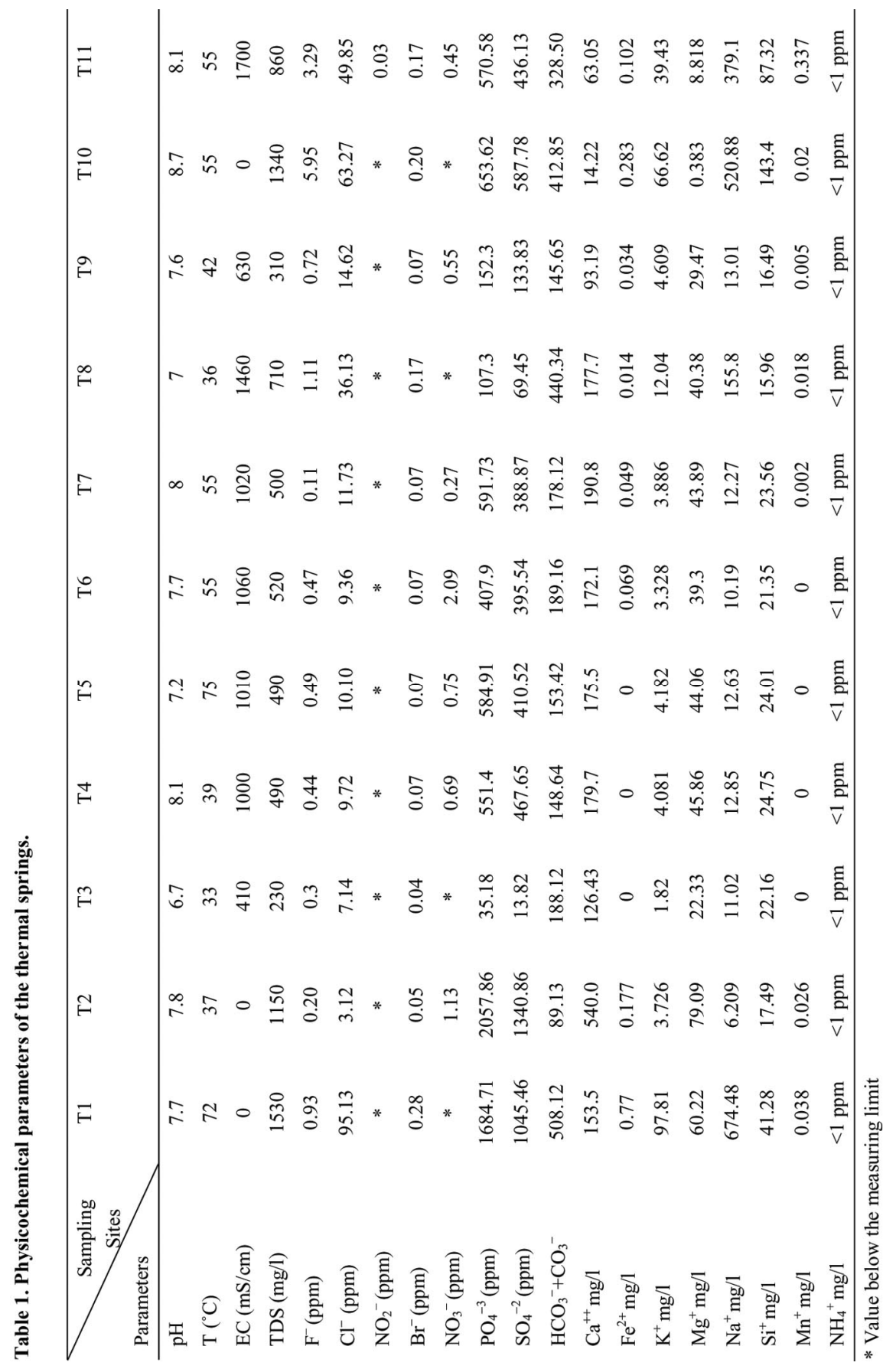


significance of their effect was supported by a Monte Carlo permutation test (499 permutations, $F$ ratio $=1.3, P$-value $=0.026$ ). As a result of the RDA analysis, the total variation was 55.45455 , and the first two axes explained a total of $57.43 \%$ of the variance (Fig. 3).
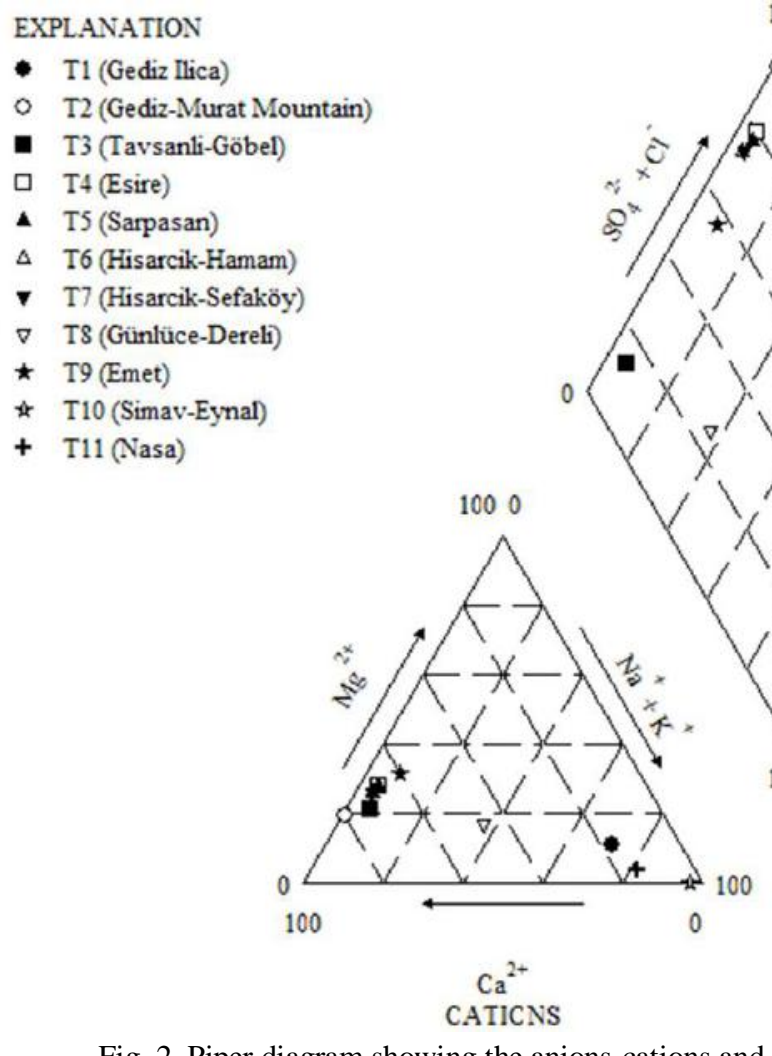

Fig. 2. Piper diagram showing the anions-cations and comparison of the thermal springs.

In the comparison of physicochemical parameters that cause species diversity and the taxa differences of the thermal springs, the question of whether the difference between them was significant with the Kruskal Wallis tests was examined. There was a significant difference $(P<0.001)$ in the comparison of physicochemical parameters including $\mathrm{pH}, \mathrm{EC}, \mathrm{TDS}$, and temperature values of the thermal springs in this study (Fig. 4). Kruskal Wallis tests showed variations in the physicochemical parameters of the thermal springs and in the cyanobacteria diversity (Fig. 5). The frequency of distribution of taxa according to $\mathrm{pH}$, TDS, T, and EC values can be seen in Fig. $6(P<0.001)$. Besides, the manganese $(\mathrm{Mn})$ values of the sampling sites were compared with the Kruskal-Wallis test in SPSS $(P<0.001)$ as a remarkable value (Fig. 7).

As a result, 54 cyanobacteria taxa were identified based on morphological characteristics. The physicochemical properties of the thermal springs were measured. In addition, statistical analyses were made to reveal in detail the physicochemical properties of the thermal springs and their comparisons with the cyanobacterial flora.

The piper diagram was provided for convenience in the classification and comparison of thermal springs in the Kütahya province; thus, the anions and cations of the water taken from the 
thermal springs (Fig. 2) were compared. According to the Piper diagram, sampling sites T1, T3, $\mathrm{T} 8, \mathrm{~T} 10$, and $\mathrm{T} 11$ were classified as a $\mathrm{Na}-\mathrm{HCO}_{3}-\mathrm{SO}_{4}$ type, and sampling sites T2, T4, T5, T6, T7, and $\mathrm{T} 9$ were classified as a Ca-Mg-SO ${ }_{4}$ type. In addition, these thermal springs in Kütahya were classified with the Piper diagram by different researchers (Gemici et al., 2004; Güneş, 2006; Bello et al., 2014). In the literature, it is noteworthy that the Piper diagram has been used less frequently in the determination of cyanobacteria in thermal springs (Singh et al., 2018b).

\section{Table 2. Cyanobacteria taxa and sampling sites.}

\begin{tabular}{|c|c|c|}
\hline $\begin{array}{l}\text { Taxa } \\
\text { code }\end{array}$ & Cyanobacteria taxa & $\begin{array}{c}\text { Thermal } \\
\text { spring }\end{array}$ \\
\hline & Chroococcales & \\
\hline 1 & Gloeocapsa sp. & T6 \\
\hline 2 & Gloeocapsopsis cyanea (Krieger) Komárek \& Anagnostidis & $\mathrm{T} 3, \mathrm{~T} 10$ \\
\hline 3 & Chroococcus membraninus (Meneghini) Nägeli & T9 \\
\hline \multirow[t]{2}{*}{4} & Cyanosarcina thermalis (Hindák) Kovácik & T6 \\
\hline & Synechococcales & \\
\hline 5 & Anathece clathrata (West \& G.S.West) Komárek, Kastovsky \& Jezberová & T1 \\
\hline 6 & Arthronema sp. & T5 \\
\hline 7 & Romeria chlorina Böcher & $\mathrm{T} 1$ \\
\hline 8 & Planktolyngbya contorta (Lemmermann) Anagnostidis \& Komárek & $\mathrm{T} 1$ \\
\hline 9 & Leptolyngbya boryana (Gomont) Anagnostidis \& Komárek & T3 \\
\hline 10 & L. tenerrima (Hansgirg) Komárek & $\mathrm{T} 8$ \\
\hline 11 & L. gelatinosa (Woronichin) Anagnostidis \& Komárek & $\mathrm{T} 7, \mathrm{~T} 10$ \\
\hline 12 & L. granulifera (J.J.Copeland) Anagnostidis & $\mathrm{T} 1$ \\
\hline 13 & L. thermarum (Woronichin) Anagnostidis \& Komárek & $\mathrm{T} 10$ \\
\hline 14 & Leptolyngbya sp. 1 & T6 \\
\hline 15 & Leptolyngbya sp. 2 & T5 \\
\hline 16 & Leptolyngbya sp. 3 & $\mathrm{~T} 4$ \\
\hline 17 & Leptolyngbya sp. 4 & $\mathrm{~T} 4$ \\
\hline 18 & Pseudanabaena minima (G.S.An) Anagnostidis & $\mathrm{T} 1, \mathrm{~T} 7, \mathrm{~T} 10$ \\
\hline 19 & P. lonchoides Anagnostidis & $\mathrm{T} 8$ \\
\hline 20 & P. thermalis Anagnostidis & $\mathrm{T} 10$ \\
\hline 21 & P. limnetica (Lemmermann) Komárek & $\mathrm{T} 10$ \\
\hline 22 & Pseudanabaena sp. & T5 \\
\hline 23 & Limnothrix mirabilis (Böcher) Anagnostidis & $\mathrm{T} 1$ \\
\hline \multirow[t]{2}{*}{24} & Trichocoleus sociatus (West \& G.S.West) Anagnostidis & $\mathrm{T} 2$ \\
\hline & $\begin{array}{c}\text { Spirulinales } \\
\end{array}$ & \\
\hline 25 & Spirulina subsalsa Oerstedt ex Gomont & $\mathrm{T} 1$ \\
\hline 26 & S. subtilissima Kützing ex Gomont & T9 \\
\hline \multirow[t]{2}{*}{27} & S. labyrinthiformis Gomont & T5 \\
\hline & Oscillatoriales & \\
\hline 28 & Geitlerinema nematodes (Skuja) Anagnostidis & $\mathrm{T} 1$ \\
\hline 29 & $\begin{array}{l}\text { Anagnostidinema amphibium (C.Agardh ex Gomont) Strunecký, } \\
\text { Bohunická, J.R.Johansen \& J.Komárek }\end{array}$ & T5 \\
\hline 30 & Planktothrix clathrata (Skuja) Anagnostidis \& Komárek & $\mathrm{T} 8$ \\
\hline
\end{tabular}




\begin{tabular}{|c|c|c|}
\hline $\begin{array}{l}\text { Taxa } \\
\text { code }\end{array}$ & Cyanobacteria taxa & $\begin{array}{l}\text { Thermal } \\
\text { spring }\end{array}$ \\
\hline 31 & Microcoleus autumnalis (Gomont) Strunecky, Komárek \& J.R.Johansen & T3 \\
\hline 32 & M. lacustris Farlow ex Gomont & $\mathrm{T} 8$ \\
\hline 33 & M. paludosus Gomont & $\mathrm{T} 2$ \\
\hline 34 & Kamptonema jasorvense (Vouk) Strunecký, Komárek \& J.Smarda & $\mathrm{T} 1$ \\
\hline 35 & K. okenii (C.Agardh ex Gomont) Strunecký, Komárek \& J.Smarda & $\mathrm{T} 9, \mathrm{~T} 10$ \\
\hline 36 & K. cortianum (Meneghini ex Gomont) Strunecký, Komárek \& J.Smarda & $\mathrm{T} 9, \mathrm{~T} 10$ \\
\hline 37 & Phormidium incrustatum Gomont ex Gomont & $\mathrm{T} 8$ \\
\hline 38 & P. terebriforme (C.Agardh ex Gomont) Anagnostidis \& Komárek & T5 \\
\hline 39 & P. thermobium Anagnostidis & $\mathrm{T} 7, \mathrm{~T} 8$ \\
\hline 40 & P. chalybeum (Mertens ex Gomont) Anagnostidis \& Komárek & T9 \\
\hline 41 & Phormidium sp. & $\mathrm{T} 4$ \\
\hline 42 & Oscillatoria subcapitata Ponomarev ex Elenkin & T8 \\
\hline 43 & O. proboscidea Gomont & $\mathrm{T} 1, \mathrm{~T} 5$ \\
\hline 44 & O. princeps Vaucher ex Gomont & $\mathrm{T} 10, \mathrm{~T} 11$ \\
\hline 45 & O. subbrevis Schmidle & T5 \\
\hline 46 & O. curviceps C.Agardh ex Gomont & $\mathrm{T} 2$ \\
\hline 47 & O. sancta Kützing ex Gomont & $\mathrm{T} 8$ \\
\hline 48 & Lyngbya martensiana Meneghini ex Gomont & $\mathrm{T} 3$ \\
\hline 49 & L. thermalis Kützing ex Gomont & $\mathrm{T} 2$ \\
\hline 50 & $\begin{array}{l}\text { Limnoraphis hieronymusii (Lemmermann) J.Komárek, E.Zapomelová, } \\
\text { J.Smarda, J.Kopecký, E.Rejmánková, J.Woodhouse, B.A.Neilan \& } \\
\text { J.Komárková }\end{array}$ & $\mathrm{T} 4$ \\
\hline \multirow[t]{2}{*}{51} & Blennothrix sp. & $\mathrm{T} 4$ \\
\hline & Nostocales & \\
\hline 52 & Nostoc sp. & T7 \\
\hline 53 & Calothrix sp. & T3 \\
\hline 54 & Hapalosiphon sp. & $\mathrm{T} 10$ \\
\hline
\end{tabular}

Although the T1 and T2 springs appear to be close to each other, the T2 source is located at a much higher altitude than the others. When the physicochemical parameters of the T1 and T2 are examined (Table 1), it is seen that the $\mathrm{pH}$ and $\mathrm{Mg}$ values are similar. However, the other parameters, particularly the temperature, are quite different. Based on their own studies, Singh et al. (2018b) stated that the close proximity of the hot springs does not mean that they may have similar physical and chemical characteristics. However, the physicochemical parameters of the T4, T5, T6, and T7 springs are quite similar, so they are seen to be in the same class in the Piper diagram and close to each other in the study area (Fig. 2).

It has been reported that there are different species compositions in different thermal springs depending on the substratum and the physicochemical parameters of springs (Ward and Castenholz, 2000; Papke et al., 2003). In the literature, there are many studies of the cyanobacterial flora in thermal springs (Sompong et al., 2005; Debnath et al., 2009; Heidari et al., 2013; Roy et al., 2015; Kanellopoulos et al., 2016; Singh et al., 2018a, Singh et al., 2018b). When compared with the literature, it may be seen that more cyanobacteria taxa were determined in this study. The main reason for this may be that there are high numbers of thermal springs and sampling sites in this study. Another possible reason may be that the thermal springs in the sampling area have different physicochemical properties. 


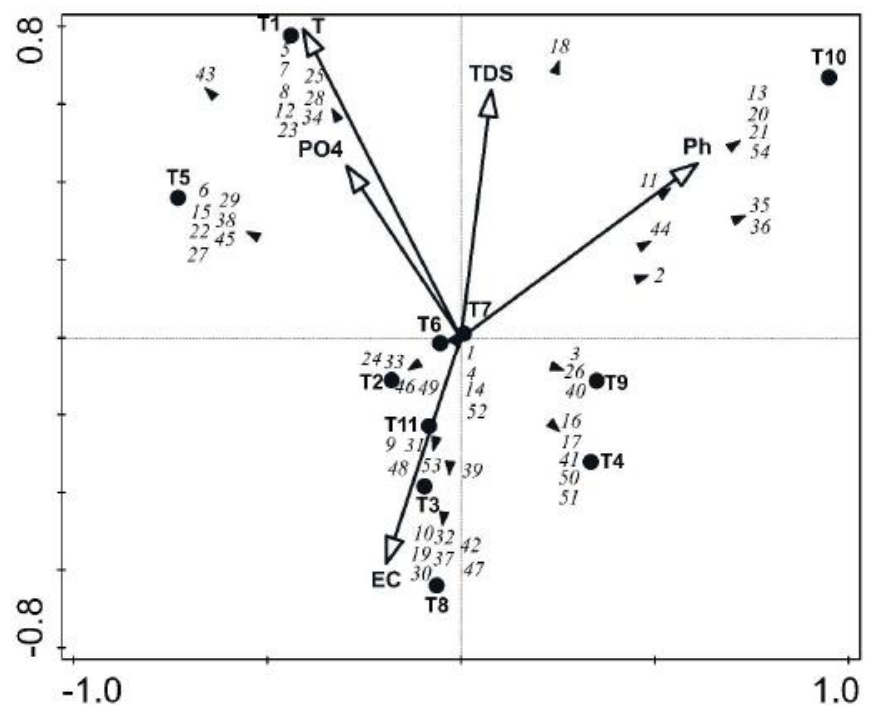

Fig. 3. RDA Diagram showing the relationship between the cyanobacteria taxa (with full triangle), the thermal springs (with full circle), and the physicochemical variables of thermal water (with arrow) [the cyanobacteria taxa code and the thermal springs where they were sampled are given in Fig. 1 and Table 2] T: temperature, EC: conductivity, TDS: total dissolved solid, and $\mathrm{PO}_{4}^{-3}$ :phosphate.
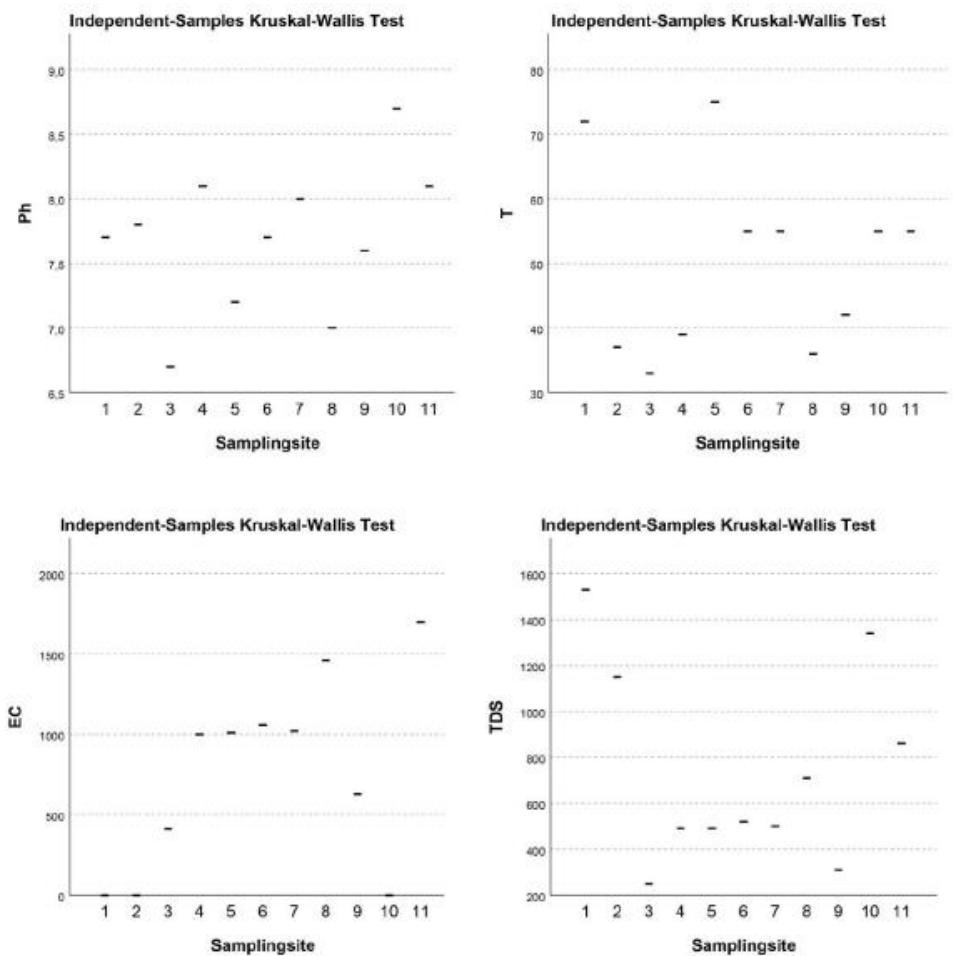

Fig. 4. Comparison of the $\mathrm{pH}, \mathrm{TDS}, \mathrm{T}$, and EC values of the sampling sites with the Kruskal-Wallis test in SPSS $(\mathrm{P}<0.001)$. 


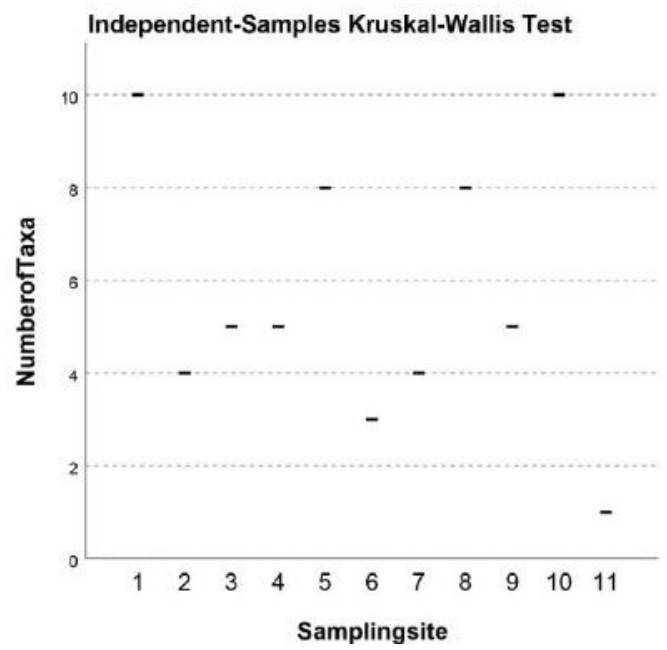

Fig. 5. Comparison of the number of taxa and the sampling sites with the Kruskal-Wallis test in SPSS.
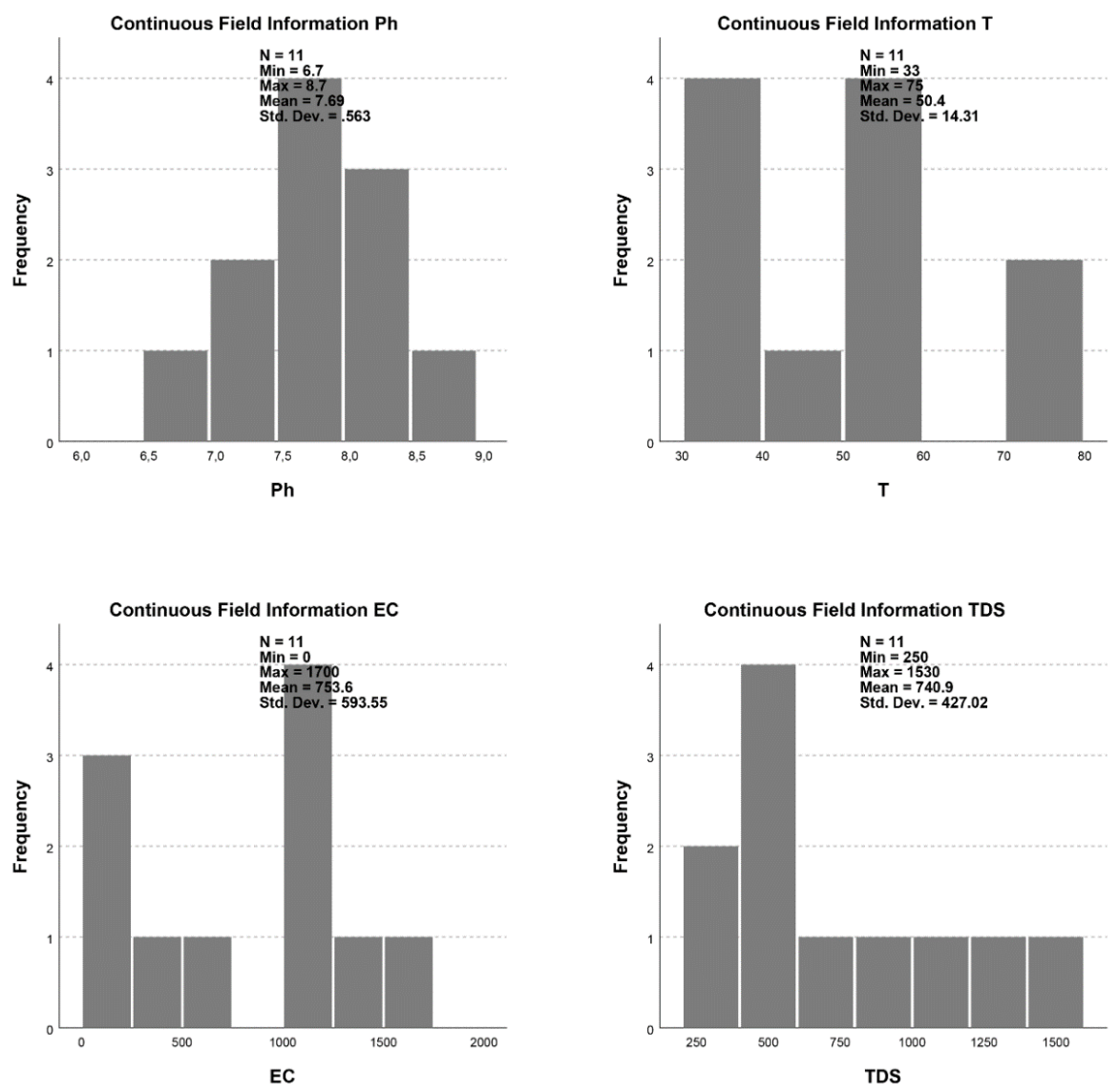

Fig. 6. Frequency of $\mathrm{pH}$, TDS, T, and EC between the taxa $(\mathrm{P}<0.001)$. 


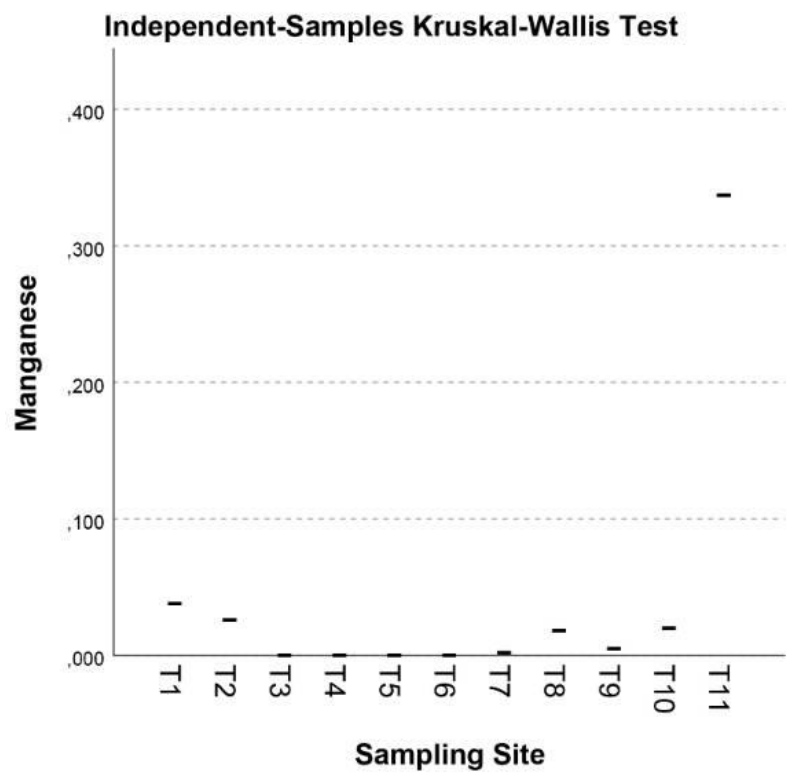

Fig. 7. Comparison of the manganese (Mn) values of the sampling sites with Kruskal-Wallis test in SPSS $(\mathrm{P}<0.001)$.

Oscillatoriales were a predominant order with taxa diversity (24 taxa) in this study. Similarly, a major component of the thermal spring's cyanobacterial flora worldwide belongs to order Oscillatoriales (Pentecost et al., 1997; Sompong et al., 2005; Mcgregor and Rasmussen, 2008; Ionescu et al., 2010; Arman et al., 2014). Nevertheless, Leptolyngbya (order Synechococcales) were determined frequently in the thermal springs of the Kütahya province. Also, this taxon is one of the most frequently reported taxa observed in thermal springs (Ulcay Öztürk et al., 2006; Mcgregor and Rasmussen, 2008). Commonly identified Pseudanabaena and Spirulina taxa in this study were also reported in other thermal springs (Heidari et al., 2013; Arman et al., 2014; Roy et al., 2015). According to the RDA analysis, the affinity of Spirulina subsalsa and Spirulina subtilissima with temperature was completely different in this study. While $S$. subsalsa was related to temperature, S. subtilissima was not. Krienitz et al. (2003) reported that $S$. subsalsa and $S$. subtilissima are closely related and have a wide ecological distribution. In addition, both taxa occur in thermal springs and in mesophilic brackish and marine habitats (Geitler, 1932).

According to the results of the RDA analysis, the presence of cyanobacteria taxa in thermal springs was related to the physicochemical parameters (Fig. 3). The RDA analysis showed that the most highly determining factor affecting the distribution of the taxa is the temperature $(\mathrm{T})$ in this study (Fig. 3). Similarly, Roy et al. (2015) reported that temperature has been one of the most important factors as far as the distribution and diversity of cyanobacteria are concerned in geothermal springs. Also, there are a lot of studies concerning this subject in the literature (Sompong et al., 2005; Debnath et al., 2009; Singh et al., 2018b).

Pseudanabaena thermalis was collected at $50^{\circ} \mathrm{C}$ and below from sampling site $\mathrm{T} 10$. Similarly, this taxon was collected by McGregor and Rasmussen (2008) at $48.6^{\circ} \mathrm{C}$ from Innot Hot Springs in Australia. Planktolyngbya contorta was clearly associated with temperature and $\mathrm{PO}_{4}$ values in this study. Similarly, $P$. contorta was sampled in the thermal springs in Himachal Pradesh, India by Singh et al. (2018a). 
Lyngbya thermalis was sampled in the form of dark green and thin mats at $36^{\circ} \mathrm{C}$ (close to spring mouth) and at $29^{\circ} \mathrm{C}$ (where the water was discharged) from the sampling site T2. Similarly, Lukavsky et al. (2011) reported that a deep blue-green growth washed directly with water of $43^{\circ} \mathrm{C}$ was colonized with $L$. thermalis; in addition, L. thermalis also dominated near the outlets of hot water of $22^{\circ} \mathrm{C}$. Arman et al. (2014) sampled $L$. thermalis at two different thermal springs from a temperatures range of $37-42^{\circ} \mathrm{C}$. Castenholz $(1969 ; 1973)$ stated that changes in species composition with concomitant changes of temperature occurred along the gradient from the mouth of the thermal springs.

Based on the RDA analysis, Gloeocapsa sp., Cyanosarcina thermalis, Leptolyngbya sp. 1, and Nostoc sp. had an affinity with low pH, T, TDS, EC, and $\mathrm{PO}_{4}$ in this study (sampling sites T6 and T7). Despite the results of the RDA analysis, $C$. thermalis was sampled at $42-38^{\circ} \mathrm{C}$ from the T6 in this study. Actually, $C$. thermalis is known as a common taxon at thermal springs (Rueda and Monroy, 2009; Komárek and Anagnostidis, 2000; Arman et al., 2014; Šaraba and Krunić, 2017).

It has been reported that Spirulina labyrinthiformis has a high tolerance for sulfides (Pentecost and Coletta, 2007; Ward et al., 2012). S. labyrinthiformis was not collected in sampling sites with higher sulfate values, but it was sampled from sampling site T5 with $410.52 \mathrm{ppm} \mathrm{SO}_{4}^{-2}$ in this study (Tables 1 and 2). Similarly, Pentecost and Coletta (2007) reported that the dominance of this taxon might be related to its tolerance of dissolved sulfide although Spirulina is scarce in sampling sites with the highest sulfide. In some hot springs in Yellowstone Park $\left(52^{\circ} \mathrm{C}\right.$ or below), a sulfideutilizing $S$. labyrinthiformis morphotype predominates near the sulfide-rich source (Ward et al., 2012).

Temperature, in combination with the availability of combined nitrogen, phosphorus and other nutrients, and/or a concentration of free sulfide also determines the cyanobacteria composition (Ward and Castenholz, 2000; Singh et al., 2018b). Sulfide rich thermal springs usually contain sulfide tolerant and sulfide utilizing Oscillatoria (Castenholz and Utkilen, 1984; Ward and Castenholz, 2000; Singh et al., 2018b). Oscillatoria princeps were sampled from sampling sites T10 and T11 with sulfate values of 587.78 and $436.13 \mathrm{ppm} \mathrm{SO}_{4}{ }^{-2}$. In the literature, O. princeps has similarly been sampled from high sulphate values in thermal springs (Heidari et al., 2013; Arman et al., 2014). However, this taxon has been recorded in thermal springs with relatively low sulphate values (Debnath et al., 2009; Roy et al., 2015). In addition, O. princeps was the only taxon detected in sampling site T1, and it had formed large mats. Also, this taxon was sampled from T10 (Table 2). According to the literature, O. princeps is perhaps cosmopolite (not marine) (Komárek and Anagnostidis, 2005). When compared to the physicochemical parameters of the sampling sites, the high manganese $(\mathrm{Mn})$ value of T11 drew attention. A comparison of the Mn values of the sampling sites with the Kruskal-Wallis test showed significant differences $(\mathrm{P}<0.001)$ (Fig. 7). The reason it was the only taxon in $\mathrm{T} 11$ may be that $O$. princeps can tolerate a high manganese value. Mn is an essential micronutrient that may become toxic if present at a high concentration (Moura et al. 2019).

Ward and Castenholz (2000) and Sompong et al. (2005) reported that $\mathrm{pH}$ is as important as temperature for cyanobacteria in thermal springs. In the RDA analysis, a negative correlation of Pseudanabaena limnetica with EC and a positive correlation with $\mathrm{pH}$ was determined in this study. In contrast, Altunöz et al. (2016) stated that P. limnetica has the highest affinity with EC and a negative correlation with other environmental variables including $\mathrm{pH}$. Cyanobacteria can be considered alkaline since they grow optimally between $\mathrm{pH} 7.5$ and above (Brock, 1973). Gloeocapsopsis cyanea was sampled from the two sampling sites with the lowest and the highest $\mathrm{pH}$ values in this study (T3, $\mathrm{pH} 6.7 ; \mathrm{T} 10, \mathrm{pH} 8.7)$. In conclusion, it can be concluded that the 
ecological valence of the taxon for the $\mathrm{pH}$ demand is wide. In the literature, this taxon was reported from different environments (Lamprinou et al., 2012; Arman et al., 2014; Ozturk Ulcay et al., 2017; Davydov, 2018). Also, Grimmett and Lebkuecher (2017) reported that G. cyanea was among the taxa determined as potential indicators of nutrient-rich areas based on their own data.

Phormidium incrustatum is known as the common taxa of the limestone/travertine/calcareous substrata (Pentecost, 2005; Couradeau et al., 2013; Kanellopoulos et al., 2016). P. incrustatum was sampled from T8, one of the stations with high carbonate and bicarbonate values in this study. Kanellopoulos et al. (2016) noted that trichomes of $P$. incrustatum are surrounded by a firm sheath of extracellular polymeric substances (EPS), constituting the locus of intensive calcification.

Because many taxa cannot tolerate high temperatures, thermal springs are extreme habitats for living organisms (Ozturk Ulcay and Kurt, 2017). Thermal springs are very difficult environments for organisms because of high temperatures and physicochemical parameters. Yet, thermal springs create special living environments. The group that has best adapted to these environments is cyanobacteria, which are photosynthetic prokaryotes. In this case, it is important to determine the diversity of cyanobacteria. However, in the literature, no sufficient study of the biodiversity of thermal springs in Turkey was found.

The Kütahya province is very rich in thermal springs, and the primary objective of this study was to determine the cyanobacterial diversity in these springs. In this study, numerous different statistical analyses were performed to reveal the physicochemical properties of the thermal springs and compare them with the cyanobacterial flora. Comparison between the physicochemical parameters and the cyanobacteria taxa was made with RDA analysis, the Piper diagram, and Kruskal Wallis tests. Since physicochemical parameters are important in understanding the ecology of aquatic habitats, many parameters were measured in this study. It is important to perform these statistical analyses to understand the ecology of the thermal springs and the cyanobacteria that prefer these environments.

\section{Acknowledgements}

I am appreciate the contributions of Dr. Oğuz KURT (PhD; Manisa Celal Bayar University, Turkey). This work was supported by the MCBU BAP, Manisa, Turkey for research, under the project FEF 2013-107.

\section{References}

Adiguzel, A., Ozkan. H., Baris, O., Inan, K., Gulluce, M. and Sahin, F. 2009. Identification and characterization of thermophilic bacteria isolated from hot springs in Turkey. Journal of Microbiological Methods 79(3): 321-328. https://doi.org/10.1016/j.mimet.2009.09.026

Altunöz, M., Obali, O., Atici, T. and Arru, L. 2016. Seasonal monitoring of algal flora in the Pamukkale travertines and thermal springs (Denizli/Turkey). Biological Diversity and Conservation 9(1): 116-127.

Arman, M., Riahi, H., Yousefzadi, M. and Sonboli, A. 2014. Floristic study on cyanophyta of three hot springs of Hormozgan Province, Iran. Iranian Journal of Botany 20(2): 240-247.

Arthur, M. and Piper, A. 1944. Graphic procedure in the geochemical interpretation of water. Analyses 25(6): 914-928. http://dx.doi.org/10.1029/TR025i006p00914

Aysel, V., Çelik, A., Yayıntaş, A. and Şipal-Gezerler, U. 1992. Zonguldak-Ilıksu Kaplıcası Alg Florası. Ege Üniversitesi Su Ürünleri Dergisi 9(33-36): 72-82.

Bello, O.A., Ozgur, N. and Calıskan, T.A. 2014. Hydrogeological, Hydrogeochemical and Isotope Geochemical Features of Thermal Waters in Simav and Environs, Thirty-Ninth Workshop on Geothermal Reservoir Engineering Stanford University, Stanford, California, February 24-26. 
Brock, T.D. 1973. Lower pH Limit for the Existence of Blue-Green Algae: Evolutionary and Ecological Implications. Science 179(4072): 480-483.

Castenholz, R.W. 1969. Thermophilic Blue-Green Algae and the Thermal Environment. American Society for Microbiology, pp. 476-504.

Castenholz, R.W. 1973. Ecology of blue-green algae in hot springs. In: Carr NG, Whitton BA (Ed.) The biology of blue-green algae. Blackwell/University of California Press.

Castenholz, R.W. and Utkilen, H.C. 1984. Physiology of sulfide tolerance in a thermophilic Oscillatoria. Archives of Microbiology 138:299-305.

Couradeau, E., Benzerara, K., Gerard, E., Esteve, I., Moreira, D., Tavera, R. and Lopez-Garcia, P. 2013. Cyanobacterial calcification in modern microbialites at the submicrometer scale. Biogeosciences 10: 5255-5266. https://doi.org/10.5194/bg-10-5255-2013, 2013.

Davydov, D. 2018. Checklist of cyanobacteria from the European polar desert zone. Botanica 24(2): 185201. https://doi.org/10.2478/botlit-2018-0018

Debnath, M., Mandal, N.C. and Ray, S. 2009. The Study of Cyanobacterial Flora from Geothermal Springs of Bakreswar, West Bengal, India. Algae 24(4): 185-193. https://doi.org/10.4490/ALGAE. 2009. 24.4.185

Demirel, Z. and Sukatar, A. 2011. Investigation of Cyanobacteria Molecular Identified and Toxin Isolated Form Izmir Thermals. European Journal of Phycology 46(1): 127-128.

Geitler, L. 1932. Cyanophyceae. In: Rabenhorst, L. (Ed.), Kryptogamen-Flora Von Deutschland, Österreich Und Der Schweiz. 14: 673-1056.

Gemici, Ü., Tarcan, G., Colak, M. and Helvac1, C. 2004. Hydrogeochemical and hydrogeological investigations of thermal waters in the Emet area (Kutahya, Turkey). Applied Geochemistry, 19: 105-117.

Grimmett, M.R. and Lebkuecher, J.G. 2017. Composition of algae assemblages in middle Tennessee streams and correlations of composition to trophic state. Journal of Freshwater Ecology 32(1): 363-389. https://doi.org/10.1080/02705060.2017.1314228

Guiry, M.D. and Guiry, G.M. 2021. AlgaeBase. <www.algaebase.org>. National University of Ireland, Galway. Retrieved on 25 March 2021.

Güner, H. 1966. Pamukkale Termal Suyunun Mikrofloras1, Biologi 19, Ege Üni. Fen Fak. İlmi Raporlar Serisi. 31.

Güner, H. 1967. Ege Bölgesi Termal Sularının Alg Vegetasyonu İle İlgili Ön Gözlemler, V. Türk Biyoloji Kongresi Tebliğleri.

Güner, H. 1970. Ege Bölgesi Kaplıca Ve Maden Sularının Alg Vegetasyonu İle İlgli İnceleme. Ege Üni. Fen Fak. İlmi Raporlar Serisi, 99.

Güneş, C. 2006. Gediz Kaplicalari'nin (Kütahya) Hidrojeolojik Ve Hidrojeokimyasal Değerlendirilmesi (Master's thesis).

Heidari, F., Riahi, H., Yousefzadi, M. and Shariatmadari, Z. 2013. Morphological and phylogenetic diversity of cyanobacteria in four hot springs of Iran. Iranian J. Bot. 19(2): 162-172.

Ionescu, D., Hindiyeh, M., Malkawi, H. and Oren, A. 2010. Biogeography of thermophilic cyanobacteria: insights from the Zerka Ma'in hot springs (Jordan). FEMS Microbiol. Ecol. 72: 103-113.

John, D.M., Whitton, B.A. and Brook, A.J. 2002. The Freshwater Algal Flora of The British Isles. Cambridge University Press.

Kalkan, E., Nadaroğlu, H. and Kılıç, S. 2020. Removal of Algae from Thermal Mud Pool for DeliçermikKöprüköy (Erzurum, Turkey). Algae 2020(2020): 1-14.

Kanellopoulos, C., Lamprinou, V., Mitropoulos, P. and Voudouris, P. 2016. Thermogenic travertine deposits in Thermopylae hot springs (Greece) in association with cyanobacterial microflora. Carbonates and Evaporites 31: 239-248. https://doi.org/10.1007/s13146-015-0255-4.

Komárek, J. 2013. Süßwasserflora von Mitteleuropa, Cyanoprokaryota 3rd Part: Heterocystous Genera. Springer Press. 
Komárek, J. and Anagnostidis, K. 2000. Süßwasserflora Von Mitteleuropa, Cyanoprokaryota 1nd Part: Chroococcales. Spektrum Akademischer Press.

Komárek, J. and Anagnostidis, K. 2005. Süsswasserflora Von Mitteleuropa, Cyanoprokaryota 2nd Part: Oscillatoriales. Spektrum Akademischer Press.

Krienitz, L., Ballot, A., Kotut, K., Wiegand, C., Pütz, S., Metcalf, J.S., Codd, G.A. and Stephan, P. 2003. Contribution of hot spring cyanobacteria to the mysterious deaths of Lesser Flamingos at Lake Bogoria, Kenya. FEMS Microbiology Ecology 43(2): 141-148.

Lamprinou, V., Danielidis, D.B., Economou-Amilli, A. and Pantazidou, A. 2012. Distribution survey of Cyanobacteria in three Greek caves of Peloponnese. International Journal of Speleology 41(2): 267-272. http://dx.doi.org/10.5038/1827-806X.41.2.12

Lukavsky, J., Furnadzhieva, S. and Pilarski, P. 2011. Cyanobacteria of the thermal spring at Pancharevo, Sofia, Bulgaria. Acta Botanica Croatica 70(2): 1-18.

Mcgregor, G. and Rasmussen, J. 2008. Cyanobacterial Composition of Microbial Mats From An Australian Thermal Spring: A Polyphasic Evaluation. Fems Microbiol. Ecol. 63: 23-35.

Moura, K.A.F., Lizieri, C., Franco, M.W., Vaz, M.G.M.V., Araújo, W.L., Convey, P. and Barbosa, F.A.R. 2019. Physiological and thylakoid ultrastructural changes in cyanobacteria in response to toxic manganese concentrations. Ecotoxicology 28: 1009-1021. http://dx.doi.org/10.1007/s10646-01902098-y

Özşahin, E. and Kaymaz, Ç.K. 2013. Türkiye'nin Termal Su Kaynaklarının Coğrafi Açıdan Değerlendirilmesi (A Geographic Evaluation of Thermal Water Sources of Turkey). J. Soc. Sci. 50: $25-38$.

Öztürk Ulcay, S. and Kurt, O. (2017). Algae Flora of Germencik-Alangüllü (Aydın, Turkey) Thermal Water. Celal Bayar University Journal of Science 13(3): 601-608. http://dx.doi.org/10.18466/cbayarfbe.339279

Ozturk Ulcay, S., Kurt, O., Ozturk, M. and Guner, H. 2017. Algae Microflora of Pamukkale Thermal Water (Unesco, 485) 45 Years Ago and Now. Fresenius Environ. Bullet 26(6): 4153-4157.

Ozturk, S. 2020. Notes on the thermal habitat: Thirteen new records for the freshwater algal flora of Turkey. Indian Journal of Geo-Marine Sciences 49(10): 1661-1668.

Papke, R.T., Ramsing, N.B., Bateson, M.M. and Ward, D.M. 2003. Geographical isolation in hot spring Cyanobacteria. Environ. Microbiol. 5(8): 650-659.

Pentecost, A. 2005. Travertine. Berlin, Germany. Springer Press.

Pentecost, A., Bayari, S. and Yesertener, C. 1997. Phototrophic microorganisms of the Pamukkale travertine, Turkey: Their distribution and influence on travertine deposition. Geomicrobiol. J. 14(4): 269-283.

Pentecost, A. and Coletta, P. 2007. The role of photosynthesis and $\mathrm{CO}^{2}$ evasion in travertine formation: a quantitative investigation at an important travertine-depositing hot spring, Le Zitelle, Lazio, Italy. J. Geol. Soc. 164: 843-853.

Piper, A.M. 1944. A graphic procedure in geochemical interpretation of water analysis. Trans. Amer. Geophys. Union 25: 914-928.

Regel, C. and Skuja, H. 1937. Süsswasseralgen aus Griechenland und Kleinasien. Hedwigia 77: 15-70.

Roy, S., Bhattacharya, S., Debnath, M. and Ray, S. 2015. Diversity of cyanobacterial flora of Bakreswar geothermal spring, West Bengal, India-II. Algol. Stud. 147: 29-44.

Rueda, C.G. and Monroy, G.H.G. 2009. Characterization of periphytic algae from Macheta and Paipa thermal springs, Colombia. SIL Proceedings 30(8): 1289-1292.

Šaraba, V. and Krunić, O. 2017. Biohydrogeology at Outflow Points of Selected Thermo-Mineral Waters in Serbia. Reports of the Serbian Geol. Soc. pp. 69-82.

Singh, V.K., Verma, D., Nayaka, S., Toppo, K. and Lavania, S. 2018a. Cyanobacterial flora from thermal springs of the Kullu District, Himachal Pradesh, India. J.Indian Bot. Soc. 97(3-4): 31-37.

Singh, Y., Gulati, A., Singh, D.P. and Khattar, J.I.S. 2018b. Cyanobacterial community structure in hot water springs of Indian North-Western Himalayas: A morphological, molecular and ecological approach. Algal Res. 29: 179-192. 
Sompong, U., Hawkins, P.R., Besley, C. and Peerapornpisal, Y. 2005. The distribution of cyanobacteria across physical and chemical gradients in hot springs in northern Thailand. Microbiol. Ecol. 52: 365-376.

Ter Braak, C.J.F. and Smilauer, P. 2012. Canoco Reference Manual and User's Guide: Software for Ordination. Microcomputer Power, Ithaca, NY, USA.

Ulcay Öztürk, S., Öztürk, M., Kurt, O. and Taşkın, E. 2006. Manisa İli ve Çevresindeki Kaplıcalarda Yayılış Gösteren Mavi-Yeşil Alg Türleri. 18. Ulusal Biyoloji Kongresi. pp. 108-108.

Ulcay Öztürk, S., Öztürk, M., Kurt, O., Taşkın, E. and Öztürk, M. 2007. Thermal Cyanophyceae (blue-green algae) species that are distributed in the thermal springs of Dikili District (İzmir). Turkish J. Aqua. Life 5-8: 371-378.

Ulcay, S. and Kurt, O. 2014a. Aydın İli Termal Sularında Yayılış Gösteren Algler. 22. Ulusal Biyoloji Kongresi, Eskişehir, Türkiye. 1186.

Ulcay, S. and Kurt, O. 2014b. Denizli İli Termal Sularında Yayılış Gösteren Algler. 22. Ulusal Biyoloji Kongresi, Eskişehir, Türkiye. 1215.

Ulcay, S. and Kurt, O. 2014c. Kütahya İli Termal Sularında Yayılış Gösteren Algler. VI. Ulusal Limnoloji Sempozyumu, Uludağ Üniversitesi, Bursa. 98 pp.

Ünal, T. 1996. İzmir Balçova (Agamemnon) Kaplıcası Mikroskobik ve Makroskobik Alg Florası (Master's thesis).

Ward, D.M., Castenholz, R.W. and Miller, S.R. 2012. Cyanobacteria in Geothermal Habitats. In: Whitton B. (Ed.), Ecology of Cyanobacteria II. Cambridge University Press.

Ward, D.M. and Castenholz, R.W. 2000. Cyanobacteria in geothermal habitats. In: Whitton B.A. and Potts M. (Ed.), The Ecology of Cyanobacteria, Their Diversity in Time and Space. Cambridge University Press.

Winston, R.B. 2020. GW Chart version 1.30: U.S. Geological Survey Software Release.

Yedier, S., Kontaş, S., Bostanc1, D. and Polat, N. 2016. Otolith and scale morphologies of doctor fish (Garra rufa) inhabiting Kangal Balıklı Çermik thermal spring (Sivas, Turkey). Iranian J. Fish. Sci. 15(4): 1593-1608.

Yuksel, K., Demirel, Z., Koçyiğit, A. and Sukatar, A. 2009. İzmir İlinde bulunan termal sularda gelişen bazı termofilik mavi-yeşil alglerin (siyanobakterilerin) izolasyonu ve moleküler tayini. E.Ü. Su Ürünleri Dergisi 26(4): 267-270. 